\title{
Developing a Marketing Strategy to Increase the Occupancy Rate: Case Study Hotel XYZ
}

\author{
Farah Hani Andini and Deddy Priatmodjo Koesrindartoto
}

\begin{abstract}
Hotel XYZ is one of the oldest local hotels in Bandung. Located in a strategic location, this hotel uses the concept of a heritage hotel. In 2017-2019, Hotel XYZ experienced a decline in performance. This happen due to lowering the occupancy rate of the rooms which results in a decrease in overall income. The increasing number of local accommodations has also increased competition between hotels with the same target market. All data used in this study are qualitative and based on primary data and secondary data. Primary data was obtained through interviews with the XYZ hotel management and internal data needs such as room occupancy rate data and financial reports. Meanwhile, secondary data comes from study literature, related news and related journals. This study aims to help Hotel XYZ, to increase the occupancy rate of rooms so that they can survive in business in this industry. Several strategies will be used in this study to increase room occupancy rates. In this research, the author will identify problems through PEST analysis, competitor analysis, customer analysis and virtual hotel operator analysis and business model canvas. From the results of the analysis, the authors found that there are conditions that are not ideal, including not maximizing marketing activities, resulting in high walk-in consumers. After carrying out procedures for analysis related to company issues, the authors compile alternative solutions that can be proposed to be able to increase the occupancy rate and hotel revenue through a marketing strategy. The author develops strategies through new wave marketing and sustainability strategies. With this strategy, marketing activities can focus more on communities such as business travelers. XYZ hotel must also conducted some additional activities such as reactivating social media and websites, updating the interior and working with parties who can support hotel marketing activities.
\end{abstract}

Index Terms - hospitality industry, occupancy rate, marketing strategy, new wave marketing, sustainability strategy.

\section{INTRODUCTION AND RESEARCH OBJECTIVES}

Bandung is West java provincial capital and also one of the big cities in Indonesia. Located about 150 kilometers southeast of Jakarta and also the largest city in the southern part of Java Island, make it to be an option for taking a vacation trip for business purpose or recreation, also education. As there are so many tourist destinations scattered all over Bandung city, it triggering increase business opportunity in the hospitality industry. The spread of hotel industry also accompanies to support the hospitality and tourism industry. A global consulting firm focused on hospitality industry (HVS), Bandung's main hotel market segments are Domestic Leisure, Business and Meeting, Incentives, Convention, and Exhibition (MICE), with Jakarta being a major feeder market due to proximity and easy access [1]. Bandung city has the second highest number of accommodation establishment after Kab. Bogor. However, Bandung city has the greatest number of room (37.109 rooms) and the greatest number of bed (48.495) in West Java compared to other regency [2]. Business competition in hospitality industry is increasingly tight as the number of accommodation provider is increase but not followed by the demand correspondingly. The oversupply condition of room occupancy in hospitality industry in Bandung become one of the reasons for the intense competition within the industry.

\section{A. Statement of the Problem}

$\mathrm{XYZ}$ Hotel is one of local hotel in Bandung. This hotel faces several challenges as being growth. This condition appeared as number of accommodations is high and make the competition tighter. XYZ Hotel is one of the oldest hotels in Bandung, established in 1920. As it awarded as a Heritage, XYZ Hotel keep maintaining the same paradigm until these days, that is Heritage. However, that paradigm no longer attract the customer and there is no particular customer who really seek for this theme in their accommodation.

The decrease in customer interest in themed hotels, eventually has an impact on revenue that can be seen from the gross profit margin ratio. XYZ Hotel has a high gross profit margin value that is above $50 \%$. However, based on trends, the gross profit margin ratio continues to decline from 2016 to 2019. This decline in revenue also came from the decline in annual room occupancy rates until 2019.

\section{B. Research Objectives}

This study aims to determine the appropriate strategy that suitable for XYZ Hotel to increase the revenue by increasing the occupancy rate. The current strategy of XYZ hotel will be evaluated, then the new marketing strategy will be formulated so it could maximize the occupancy rate to increase $\mathrm{XYZ}$ Hotel's. 


\section{RESEARCH MethodolOGY}

The research method used in this study is from literature study, analytical management tools and supporting data related to this study. The data will be collected by using primary data and secondary data in order to gain information for analysis. The primary data is data that directly collected by the author. The secondary data is data that already available from other sources that author is able to used. The secondary data collection will be conducted by study literature, market data, company internal data and another article related. Qualitative method will conduct by using depth interview and observation with internal parties to get more insight into company issues. The analytical tools are obtained from the internal and external analysis that use PEST analysis, competitor analysis, customer analysis, and business model canvas. The business model canvas will evaluate using SWOT. The result of the analysis will help to formulate the suitable strategy for XYZ Hotel.

\section{EXTERNAL ANALYSIS}

External analysis is to determine the opportunities and threats that occur, both in the macro-environment, industry, and competition. External analysis in this study is carried out through PEST Analysis, competitor analysis, and customer analysis.

\section{A. PEST Analysis}

\section{Political/Legal}

Political defines the impact of local regulation on industry. The political environment includes factors that select national leadership, create laws, and provide a process for discourse on a wide range of issues [3]. It could also be the changes of government and social movement, that may cause a significant effect for business.The emerge of Covid19 outbreak required government to arrange a strategy in form of regulation in order to break the distribution chain of the virus.

Pembatasan Sosial Berskala Besar (PSBB) applied in several provinces in Indonesia which is in the red zone. In mid-April 2020, Governor of West java, Ridwan Kamil, began to apply PSBB in West Java [4]. A number of activities will have a restriction, include hospitality industry. Based on the governor's regulation 27/2020, regarding PSBB guidelines, the hotel business will be required to conduct a restrictions and obligations. In order to keep the business running, there are some new regulation and obligation that hotel must obey. In article 8 paragraph 4 , stated that hotel management must provide special services for guest who have desire to do an independent isolation.

\section{Economic}

Economic is one of other elements of macroeconomic. The economic environment includes factors that influence consumer purchase ability and buying behavior. Inflation rates, income levels, and unemployment levels all contribute to the economic environment. Recently, Indonesia has suffered due to outbreak of Covid19 that also impact economic globally. The case of the spread of Covid19 can affect the economy from two points of perspective, that is demand and supply [5].
From demand side, this condition will reduce the consumption sector through travel and transportation activities and eventually increase transportation and trade costs. From supply side, there will be a contraction in worker and labor productivity, decrease of investment and funding activity and also disruption of global value chain. From production side, sector that most affected by the spread of COVID19 is manufacturing industry. The contribution of this sector is quite significant to Indonesian economic and again, Indonesia is still depending on imports, which most come from China. From consumption side, people behavior of consumption patterns will change. They will tend to buy basic necessities rather than doing leisure activities and reduce travel activities. As a result, restriction of activity is applied that has an impact on economic downturn and affects power of buying of consumer. This event will eventually impact on hospitality industry. People will reduce or cancel their trip because business is in difficult time. Some of Indonesia's aviation and tourist destination will close temporary or reduce the flight hours that will affect the reducing of the occupancy rate of hospitality industry.

\section{Socio-Cultural}

The rapid development of economic and technology in Indonesia contribute the changes in customer behavior. Technology makes it easy for consumers to acquire what they want by providing many choices. The economy can also affect consumers' perceptions of a product. This includes the hospitality industry. In the past, hotel owners will compete to improve the quality of hospitality services and facilities such as swimming pools and fitness, in order to attract the attention of potential customers. As the number of new local tourist attractions managed by local or private governments grow, it has an impact of increasing the number of accommodations with affordable prices. This accommodation targets young people who like to travel but with a limited budget.

\section{Technology}

As one of the industries that provides services, the presence of technology can create unique value. Technology not only revolutionized in terms of consumer preaching, but also provided convenience from the business side. In the last 5 years, in terms of technology, the hospitality industry in Indonesia has come with an internet-based digital technology platform, namely the Online Travel Agent (OTA) and Virtual Hotel Operator (VHO).

\section{B. Competitor Analysis}

Competitor analysis is conducted to understand the surrounded competitor's strategy. Competitor analysis must constantly compare its marketing strategies, product, prices, channels, and promotions with those of close competitors [6]. This analysis will help the business to prepare an anticipated profile for each competitor. This research is conducted competitor analysis by comparing another hotel within $1 \mathrm{~km}$ radius from XYZ Hotel. The competitors are selected based on similarity standard as a local hotel, such as from the similar located, facility, rating, price rate, and hotel class. There are four hotels that are selected to be compared, that are The Palais Dago Hotel, Utari Hotel, M Premiere Hotel and Hay Hotel.

Overall, both XYZ Hotel and other hotels have good rating and have not much any different from each other. It can be 
concluded that, each hotel has their own strategic, by providing the room type and facilities that are not much different at a fairly affordable price, also located strategically not far from XYZ Hotel. It shows that competition between each hotel has the same market share and makes competition tighter.

\section{Customer Analysis}

In the past few years, traveling has not become a luxury activity anymore. People no longer need to wait for long holidays or have a lot of money to travel. This phenomenon is often referred to as budget travel.

The term budget travel is quite popular among millennials. Millennial is a generation born between 1981-1995. This generation will enter the peak earnings and spending year, which will be an opportunity for the travel and hospitality industry. There are some differences in the characteristic of millennial traveller in Asia, which the four country selected for the study are China, India, Singapore and Indonesia [7].

The phenomenon of budget travel is also taken by business people as an opportunity, including accommodation business. The high interest in budget travel also develops the growth of the budget hotel business that offers accommodation at affordable prices. Indonesia millennial segment put price as the most consideration in choosing accommodation, followed by strategic location, good reviews, and WIFI.

To sum up the customer analysis, millennial segments are very attractive for business people, including hospitality business. In term of travel activity, Indonesia millennial have a tendency to have an impulsive travel, even more if promotion is available. Millennial are really aware of technology and easiness to do something, so they mostly relied on technology and internet to find accommodation and booking process.

\section{INTERNAL ANALYSIS}

Business model canvas is a strategy in management of how the company creates value and generate benefit from the value created. This model to quickly get the main idea of a business. It also allows us to get an understanding about the business by making the connection between the idea and how it will work eventually. This model also allows the customer decision influence the business process. The business model canvas is in the form of a visual chart consisting of 9 elements [9].

After the initial business model is defined, the mapped business model will be evaluated. An effective way to do this is to combine a classic analysis of strengths, weakness, opportunities, and threats in a SWOT analysis with the business model canvas [9]. The SWOT analysis is used to evaluate the ongoing business model then create an alternative strategy formulation based on the result of SWOT analysis.

These 9 (nine) elements will be group into 4 strategic issues, which are value proposition, cost structure (revenue streams and cost structure), infrastructure management (key structure, key partnership, key resources), and customer relationship (customer relationship, customer segment, channels).

\section{Customer segment}

$\mathrm{S}$ : target customer comes from various age and regions.

$\mathrm{W}$ : customer comes by rack rate is quite high compare to customer with early reservation.

O: target the business traveler to maximize the occupancy rate during weekday.

$\mathrm{T}$ : the desire of customer to try various other hotels.

\section{Value proposition}

S: using the concept of heritage, offering a home-feel hotel.

$\mathrm{W}$ : the concept used are no longer able to increase customer attraction.

O: there are few customers who like classic hotels with historical value.

T: customer who are not aware of the hotel concept and prefer to choose other hotels.

\section{Channels}

S: has various channel to promote the hotel, has its own website and social media, registered in various OTA.

W: the website and social media haven't been updated for a long time.

O: easy for everyone to access information.

$\mathrm{T}$ : transparency in this strategy has a tendency to be easily imitated.

\section{Revenue stream}

S: the biggest source of hotel revenue comes from the core business itself, which is room rental.

$\mathrm{W}$ : no other large source of revenue can be utilized.

$\mathrm{O}$ : there is no significant opportunity in revenue stream segment.

$\mathrm{T}$ : there is no significant threat in revenue stream segment. 5. Key resource

$\mathrm{S}$ : efficiency of structure organization and management of human resource, adequate hotel facility.

$\mathrm{W}$ : no specific person to run the marketing department, some furniture must be replaced.

O: there are human resource with capability that can be employed to meet the needs of the hotel.

$\mathrm{T}$ : many hotels offer better facilities with the same price.

\section{Customer relationship}

$\mathrm{S}$ : staff are considered friendly by hotel guest based on OTA reviews.

W: lack of follow-up activities for guests who have stayed.

O: customer satisfaction may have them to re-visit the hotel, targeted a community.

$\mathrm{T}$ : criticism from customer who hasn't satisfied.

\section{Key activities}

S: all activities conducted are connected each other to create value.

$\mathrm{W}$ : marketing activities are not maximized.

O: there are other parties that can be used to help hotel in marketing.

$\mathrm{T}$ : other hotels also offer similar service.

\section{Key partnership}

S: partnership with those who helps hotel more effective and efficient such as OTA and third party.

$\mathrm{W}$ : there is no significant weakness in key partnership element.

O: partner with virtual hotel operator (VHO).

$\mathrm{T}$ : many other hotels that also partner with VHO. 


\section{Cost structure}

$\mathrm{S}$ : focus on value-driven, all activities are conducted to aim productivity.

$\mathrm{W}$ : the fixed costs of hotel are quite large.

$\mathrm{O}$ : there is no significant opportunity in cost structure segment.

$\mathrm{T}$ : there is no significant threat in cost structure segment.

\section{BUSINESS ISSUE SOLUTION}

In this chapter, author will elaborate the business solution after conducted the external and internal analysis from the previous chapter. A new strategy is formed to create new value for XYZ Hotel. The business strategy consists of marketing strategy and sustainability strategy.

\section{A. New Wave Marketing}

In new wave marketing, marketers and customers are at the same level (horizontal era). The customers are no longer an object, but a subject. Companies will be able to create value and competitive advantages if the customer involves in the business process. In new wave marketing, those elements change into "The $12 \mathrm{C}$ of New Wave Marketing" [11].

\section{a. Segmentation to Communitisation}

There are several communitisation strategy that XYZ Hotel can be applied. First, for it should aim business traveler. Business travelers actually a very attractive segment, they could be a person or a subgroup from a community. Second, a university or organization. XYZ Hotel is located strategically in Jalan Sawunggaling, that is close to some university in Taman Sari, that are University Islam Bandung (Unisba), University of Pasundan, and Institut Teknologi Bandung (ITB).

\section{b. Targeting to Confirmation}

$\mathrm{XYZ}$ Hotel for confirmation strategy is to make sure the business traveler or organization willing to be contacted by management. Management can follow up the customer via email or message, even better for the guest if they willing to follow XYZ Hotel's social media.

\section{c. Positioning to Clarification}

As it was mentioned in confirmation, social media has an important role as the customer are able to access all the information wherever and whenever. For clarification strategy, XYZ Hotel need to prove the quality of their service by showing the update of hotel's current activity. It also can be seen from the testimony of visited guest through review from online travel agent, such as traveloka.

\section{d. Differentiation to Codification}

In codification, strategy for XYZ Hotel is to make services as personalized as possible for the customer. This can be obtained through an evaluation of hotel guests who have stayed or it can be from the review from online travel agent.

\section{e. Product to Co-creation}

As a service provider, XYZ Hotel may not be too related to co-creation. However, XYZ can ask for advice or opinions to their customers through social media, websites or questionnaires directly to improve their service quality.

\section{$f$. Price to Currency}

In currency strategy, XYZ Hotel can determine the price by divide them based on the service needed. For example, $\mathrm{XYZ}$ Hotel is no longer include breakfast into the room charge, for the efficiency and the guest hotel has no problem with it.

\section{g. Place to Communal Activation}

XYZ Hotel can conduct an activity where the community can gather and interact. For instance, XYZ Hotel can provide place to held a bazaar or create a seasonal event such as break fasting or reunion

\section{h. Promotion to Conversation}

XYZ Hotel must able to provoke further conversation with their customers. This can be done in several ways, for instance actively using social media by giving small quizzes or polling about topic relevant to the hotel or current news. The other way is by replying the review given by the customer through social media or online travel agents.

\section{i. Selling to Commercialization}

Successful commercialization will create long-term and sustainable relationship and will occur if customer and management are willing to work together. For instance, old and damage furniture can be replaced. It doesn't have to be new furniture, but XYZ must maintain its cleanliness and uniqueness of the hotel. When customer find it attractive, customers are willing to take a photo of the hotel and post it in their social media.

\section{j. Brand to Character}

For character strategy, XYZ can create a tagline that is easy to remember and reflects the character of the hotel. This tagline does not have to made from the internal hotel, but hotel can hold a contest to create a tagline so that customers can also participate.

\section{k. Service to Care}

XYZ Hotel should able to provide more personalize service yet fun staying. This could include offering breakfast, snack meal, quick laundry service, fast connectivity and fast service. As the technology is emerged, hotel should provide an app or platform to make check-in and check-out activity efficient.

\section{l. Process to Collaboration}

In collaboration strategy, technology and internet will support the connection. For example, customer of XYZ Hotel that make reservation through telephone or hotel's website can get a tracking of how their reservation is going, which room and facility are available.

\section{B. Sustainability Strategy}

Sustainability aspects are divided into three subgroups according to the three dimensions of sustainable development [12]:

\section{Economic dimension}

Economic dimension is often discussed as 'generic dimension'. This dimension consists of activities that required for a business to remain exist in the market for a long time, such as innovation and technology, collaboration, knowledge management, process, purchase, and sustainability reporting.

This is in line with the business excellent model (BEM) for the hospitality industry. The most important factors, influencing the success of business model in the hospitality industry are as follows: Innovation, Empowered employs, Customer relationship management, Technology, Internal marketing, Value proposition [13]. 


\section{Ecological dimension}

There are a few activities that XYZ Hotel can follow to support the ecological sustainability such as using LED bulb or using sensor based light at some areas in the hotel, reducing plastic bottle by making it as request item, if possible, using a refillable shampoo or shower gel containers instead of packaged toiletries, or offering bicycle for hotel guest as an option of transportation.

\section{Social dimension}

Both internal and external stakeholder are important for XYZ Hotel persistency. A strategy to maintain good relationship with stakeholders is by stay informed and transparency, especially during the pandemic. The hotel can start by identifying an official source about public health guidance and stay up to date. The hotel needs to be able to show that they have given accurate information, so that it can built trust for stakeholder.

\section{CONCLUSION}

$\mathrm{XYZ}$ Hotel is one of local hotel in Bandung. This hotel faces several challenges as being growth. This condition appeared as number of accommodations is high and make the competition tighter.

Based on the internal analysis that has been done above, $\mathrm{XYZ}$ Hotel is not utilize the use of social media to promote the hotel. This is also due to the absence of adequate human resources to manage the marketing activity. The decreasing of revenue is also cause by the external factor that can't be predicted. This study formulates some strategies that proposed to increase the occupancy rate. The strategies are new wave marketing, and sustainability strategy. This new strategy expected to increase revenue from room rental by utilizing the community, social media, and taking advantage of occupancy fulfilment on weekdays.

\section{REFERENCES}

[1] HVS. (September 2015). Indonesia Hotel Watch 2015. [online]. Available: https://www.hospitalitynet.org/file/152005690.pdf

[2] Badan Pusat Statistik. (2020). Perkembangan tingkat penghunian kamar hotel di jawa barat. [online\}. Available: https://jabar.bps.go.id/pressrelease/2020/04/01/795/tingkatpenghunian-kamar-hotel-di-jawa-barat-februari-2020-sebesar-46-47persen.html

[3] M. Levens, Marketing: defined, explained, applied, second edition, pearson, 2014, ch 18, pp. 17-20.

[4] West Java Province. Peraturan Wali Kota Bandung, tentang pelaksanaan pembatasan social berskala besar dalam penanganan corona virus disease 2019, 2020

[5] Y. Damuri and F. Hirawan, Mengukur dampak COVID-19 pada pertumbuhan ekonomi dan perdagangan Indonesia 2020, CSIS Commentaried DMRU-015, 2020

[6] P. Kotler and G. Armstrong, Principles of marketing, $17^{\text {th }}$ Edition, Pearson, 2018, ch. 2, pp. 542-544

[7] Asia Travel Leaders' Summit, 2013, Capturing the Asian millennial $\begin{array}{lll}\text { traveller. } & \text { [online]. Available: }\end{array}$ https://www.visitsingapore.com/content/dam/MICE/Global/bulletinboard/travel-rave-reports/Capturing-the-Asian-MillennialTraveller.pdf.

[8] Jakpat, 2019, 2019 travel survey: millennials accommodation preferences. [online]. Available: https://blog.jakpat.net/2019-travelsurvey-millenials-accommodation-preferences/

[9] A. Osterwalder and Y. Pigneur, Business model generation, Wiley, 2020, chp. 1, pp. 14-44.

[10] H. Kartajaya, 2010, From legacy to new wave marketing, The
Singapore Marketer. [online]. Avaliable: : http://usaei.smu.edu.sg/

[11] R. Baumgartner and D. Ebner, Corporate sustainability strategies: sustainability profiles and maturity levels, Wiley, 76-89, 2010.

[12] N. Langviniene and I. Daunoraviviute, Factors influencing the success of business model in the hospitality service insutry, Procedia, 902-910, 2015.

[13] B. Bensoussan and C. Fleisher, Analysis without paralysis: 12 tools to make better strategic decisions, Pearson, chp. 11, pp. 387-393.

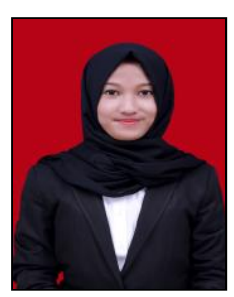

Farah Hani Andini was born on July 4, 1995, in Medan, South Sumatera, Indonesia. She earned a bachelor's degree from Bogor Agricultural of University (IPB) in 2016 majoring in management, Economic and Management Faculty.

She is currently pursuing her master's degree in Master of Business Administration at Bandung Institute of Technology, Indonesia.

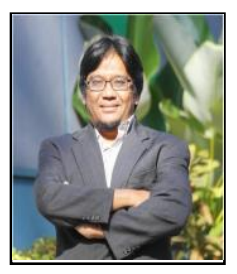

Deddy Priatmodjo Koesrindartoto earned his Ph.D in Economics with a minor of Statistics, and an MSc. In Industrial Engineering, all from Iowa State University. He also earned first degree in Electrical Engineering from ITB, Bandung. He is an Assistant Professor at the School of Business and Management, Institut Teknologi Bandung (SBM ITB).

He was the former Director of Graduate Programs of Management Science in SBM ITB, oversees both Master and PhD Programs. Before that assignment, He served as Director of Institutional Development and Planning at SBM ITB. Currently Deddy is the Head of Capital Market and Investment Laboratory and the Head of Kresna - SBM ITB Financial Trading Center, School of Business and Management ITB. Prior to joining SBM ITB in 2005, He was a Research Fellow at the Center for Computational Finance and Economics Agents (CCFEA) at the University of Essex, UK. He spent three years working for energy services industries before pursuing graduate studies. 